\title{
TRŽIŠTE RADA U EUROPSKOJ UNIJI I REPUBLICI HRVATSKOJ
}

Dr. sc. Nenad Božikovic**

\author{
UDK 331.5.024.5(4)(497.5) \\ https://doi.org/10.30925/zpfsr.42.1.5 \\ Ur.: 16. lipnja 2020. \\ Pr.: 16. listopada 2020. \\ Prethodno priopćenje
}

\section{Sažetak}

Hrvatsko gospodarstvo obilježava velika nezaposlenost $i$ spora dinamika otvaranja novih radnih mjesta zbog više čimbenika, uključujući i nefleksibilno tržište rada. Rad daje teorijski pregled komponenti tržišta rada, ponudu $i$ potražnju na tržištu rada, diskriminacije na tržištu rada, fleksigurnost, nezaposlenost kao i pitanje politike zapošljavanja uspoređujući kretanja u Europskoj uniji i Republici Hrvatskoj. U zaključku se razmatraju konkretne mjere za poboljšanje stanja na tržištu rada u Republici Hrvatskoj.

Ključne riječi: tržište rada; nezaposlenost; diskriminacija; zapošljavanje.

\section{UVOD - PONUDA I POTRA ŽNJA NA TRŽIŠTU RADA}

Tržište rada označava ponudu i potražnju radnika, njihovu pripremu, zapošljavanje, napredovanje, otkaz, čekanje na posao, konkurenciju u traženju posla i na samom poslu. ${ }^{1}$ Dio je slobodnog kretanja robe, kapitala i rada na lokalnoj, nacionalnoj i svjetskoj razini. Hrvatsko gospodarstvo obilježava visoka nezaposlenost te spora dinamika otvaranja novih radnih mjesta zbog više čimbenika, uključujući i nefleksibilno tržište rada. Izlaskom iz socijalizma stvoreni su uvjeti oslobađanja većega broja radnika i nastanak tržišta rada. Na hrvatsko tržište rada utječu: proces globalizacije, demografski trendovi te gospodarski procesi koji su devedesetih godina 20. stoljeća smanjili potražnju za radnom snagom.

Razvojem tehnologije otvorila se mogućnost fleksibilnoga radnog vremena i rada od kuće. Korištenjem mobitela, laptopa i interneta, radnik nije nužno fizički vezan za ured i fiksno radno vrijeme, što može dovesti do smanjenja troškova za radnika i poslodavca. Radom od kuće otvara se mogućnost zarade dodatnim poslom u skraćenom radnom vremenu.

* Dr. sc. Nenad Božiković, profesor visoke škole i vanjski suradnik visoke škole Banja Luka College; jbozikovina@gmail.com. ORCID: https://orcid.org/0000-0001-6140-0639.

1 Vidi, npr. Bruno Grbac, Marketinške paradigme (Rijeka: Ekonomski fakultet Rijeka, 2010.); Marija Bušelić, Tržište rada: teorijski pristup (Pula: Fakultet ekonomije i turizma Dr. Mijo Mirković, 2014.), 10; Ivo Družić, Resursi i tržišta hrvatskog gospodarstva (Zagreb: Politička kultura, 2004.), 99. 
Od početaka europskih integracijskih procesa, unutrašnje/zajedničko tržište bitna je ideja stvaranja Europske ekonomske zajednice. U skladu s čl. 26. st. 2. Ugovora o funkcioniranju Europske unije (dalje: UFEU) unutrašnje/zajedničko tržište određeno je kao područje bez unutrašnjih granica na kojem se slobodno kretanje roba, osoba, usluga i kapitala osigurava u skladu s odredbama Ugovora. „U slučaju unutrašnjeg tržišta riječ je o 'prostoru' kojeg karakterizira odsustvo međudržavnih granica, odnosno gledano iz kuta Zajednice, odsustvo unutrašnjih

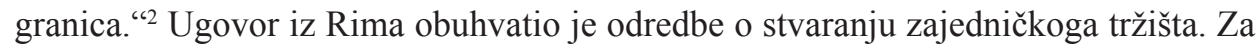
uspostavljanje tržišta važno je usvajanje: „Bijele knjige“ o kompletiranju unutrašnjeg tržišta iz 1985., ${ }^{3}$ Jedinstvenog europskog akta iz 1986., kojim je izmijenjen Ugovor iz Rima i uspostavljena pravna osnova za njegov nastanak te usvajanje Ugovora iz Maastrichta 1992. „Imajući u vidu judikaturu Europskog suda, a ona je i ovim povodom imala izuzetno značajnu ulogu, ključni pravni instrumenti konstituiranja ovakvog prostora su principi, odnosno ideje: (osnovnih) komunitarnih sloboda; uzajamnog priznavanja i ujednačavanja, odnosno harmonizacije prava."4 Temeljne su slobode izvorna konstitucijska prava Europske unije (dalje: EU). ${ }^{5}$ Održivi razvoj Europe temelji se na uravnoteženom ekonomskom rastu i stabilnosti cijena, visoko konkurentnoj socijalnoj tržišnoj privredi, u cilju pune zaposlenosti i društvenog napretka te visokoj razini zaštite okoliša. Suzbija se društvena isključenost i diskriminacija, promiče socijalna pravda i zaštita, ravnopravnost žena i muškaraca, međugeneracijska solidarnost i zaštita prava djeteta. Promiče se ekonomska, socijalna i teritorijalna kohezija te solidarnost među državama članicama. ${ }^{6}$

Radnu snagu na određenom tržištu rada privlači visina plaće kao osnova egzistencije radnika ako na njima postoji potražnja za određenom stručnom kvalifikacijom. Vrijeme kvalifikacije važno je pri izboru zanimanja kao omjer uloženog vremena radnika i očekivane plaće. Tehnološki razvitak dinamizira se velikom brzinom pa je neizvjesnost izbora $u$ porastu te se pozornost pridaje predviđanjima potreba. Visoka stopa nezaposlenosti, višak ponude nad potražnjom u RH nisu posljedica kratkoročne neravnoteže već upućuju na dugoročnu neravnotežu s negativnom dinamikom, bez obzira na to što demografski i migracijski činitelji smanjuju pritisak na tržište rada i stopu nezaposlenosti. Potrebno je pokrenuti gospodarstvo i ekspanziju uslužnog sektora, što bi srednjoročno rezultiralo pozitivnim kretanjima na tržištu rada. Ožiljke na tržištu rada ostavila je globalna

2 Nevenko Misita, Evropska unija - Institucije (Sarajevo: Revicon, 2009.), 308.

3 Povjerenstvo je 1984., kojim je predsjedavao Jacques Delors, odabralo jedinstveno europsko tržište kao prioritet svoga rada. Lord Cockfield, potpredsjednik Komisije izradio je nacrt Bijele knjige o unutarnjem tržištu - ambiciozne, ali izvodljive strategije uključujući zakonodavni program oblikovan da ukloni prekogranična ograničenja i povrati momentum ekonomske integracije. Neophodne institucijske promjene sadržane su u Jedinstvenom europskom aktu iz 1987. Ali M. El-Agraa, The European Union - Economics and Policies, $8^{\text {th }}$ ed. (Cambridge: Cambridge University Press, 2007.), 131.

4 Misita, Evropska unija - Institucije, 308.

5 Pedro Caro de Sousa, The European Fundamental Freedoms - A contextual approach (Oxford: Oxford University Press, 2015.), 1.

6 Vidi: Friedl Weiss, Klaupa Clemens, European Union Internal Market Law (Cambridge: Cambridge University Press, 2014.), 1-10. 
kriza od 2007. do 2009. Neprilagođenost tržišta promjenama posljedica je više čimbenika: rigidnost, zatvorenost i fragmentiranost tržišta; neinformiranost aktera o funkcioniranju tržišta rada i djelovanju institucija. Samoreguliranje tržišta rada je upitno što je dovelo do potrebe za državnim intervencionizmom. Posljedica recesije rast je stope nezaposlenosti i potrebe za korekcijama na tržištu rada primjenom mjera zapošljavanja u svrhu prevladavanja tržišnih nedostataka uzrokovanih krizom.

Promocija zaposlenosti srž je programa i socijalne politike Međunarodne organizacije rada (dalje: MOR) i država članica. ${ }^{7}$ Eurostat definira nezaposlenu osobu kao nekog između 15 i 74 godine starosti bez posla u referentnom tjednu (osobe koje su obavljale bilo koji posao za plaću u gotovini ili u naturi ili za obiteljsku korist), koji može započeti s radom u sljedeća dva tjedna i ako aktivno traži zaposlenje u posljednja četiri tjedna. ${ }^{8}$ Temelj potražnje za radnom snagom spremnost je poslodavca da zaposli određeni broj radnika, što ne mora biti dugoročno. Potražnja za radom izvedena je jer ovisi o potražnji za proizvodom ili uslugom. ${ }^{9}$ Potražnja će biti viša ako je proizvodnost rada visoka te ako taj proizvod postiže višu cijenu. Brojni čimbenici određuju potražnju za radom, npr. nadnica, promjena tehnologije, promjene cijene ostalih čimbenika očekivanja te preferencije poslodavca. Niža cijena radne snage temeljni je element njezine potražnje. Viša cijena radnoga sata dovodi do porasta nezaposlenosti ili sporijega zapošljavanja pri nepromijenjenim ostalim uvjetima. ${ }^{10}$ Potražnja za radom ne ovisi samo o trenutačnim potrebama poslodavca, već i o predviđanjima budućih kretanja.

Preferencije poslodavaca utemeljene na raznim čimbenicima utječu na količinu traženog rada, broj zaposlenih, njihovo iskustvo pa i dob. ${ }^{11} \mathrm{RH}$ karakterizira velika ponuda, a mala potražnja, nekompetentnost i nemobilnost radne snage.

Nužno je analizirati buduću potrebu za radnim mjestima, pripremiti se za ta zanimanja, uskladiti ponudu i potražnju. Nužno je uskladiti kompetencije radne snage za radna mjesta, prevladati prostornu neusklađenost $\mathrm{i}$ otpor mobilnosti. $\mathrm{U}$ suprotnom, povećana nezaposlenost mladih i školovanih uzrokuje odljev „mozgova“ iz RH.

Ponuda i potražnja za radom imaju posebne karakteristike. Glavna je da je riječ o tržištu ljudske radne snage. Povoljno stanje u gospodarstvu utječe na veću potražnju za radom. Najtraženiji su radnici koji imaju široko znanje i sposobnosti (uključujući timski rad), osnovna i specijalistička znanja, informacijsko-komunikacijska i znanja stranih jezika, čime postižu prilagodljivost promjenama na tržištu rada, ${ }^{12}$ iako kod

7 Jean-Michel Servais, International Labour Law, $3^{\text {rd }}$ ed. (The Hague: Wolters Kluwer, 2011.), 16.

8 Eurostat statistics, pristup 19. siječnja 2020., http://ec.europa.eu/eurostat/statistics-explained/ index.php/Unemployment_statistics.

9 Ivan Pavić, Đuro Benić i Iraj Hashi, Mikroekonomija (Split: Sveučilište u Splitu, 2006.), 451; Družić, Resursi i tržišta hrvatskog gospodarstva, 91.

10 Daniel S. Greenberg, „Participation in Public Employment Programs“, u: Creating Jobs-Public Employment Programs and Wage Subsidies, ed. John L. Palmer (Washington: The Brookings Institute, 1978.), 323.

11 Družić, Resursi i tržišta hrvatskog gospodarstva, 91-92.

12 Predrag Bejaković, „Ispadanje iz obrazovanja kao odrednica zapošljivosti“, Radno pravo 4, br. 11 (2011): 54. 
zapošljavanja nad osobinama radnika prevladavaju ekonomski kriteriji tržišta.

\section{DISKRIMINACIJA NA TRŽIŠTU RADA}

Diskriminacija (lat. discriminare, odvajati) podrazumijeva nejednako postupanje prema osobama, skupinama ili pojedincima, koji se razlikuju po nekim svojstvima. $\mathrm{Na}$ tržištu rada pojavljuju se različiti oblici diskriminacije. Načelo proklamira Povelja UN-a i Opća deklaracija o pravima čovjeka iz 1948. Konvencija UN-a o ukidanju svih oblika diskriminacije žena (CEDAW) iz 1981. te Ustav RH, članak 14. Zakon o suzbijanju diskriminacije u RH od 2009. zabranjuje diskriminaciju na temelju rase, etničke pripadnosti, boje kože, spola, jezika, vjere, političkog ili drugog uvjerenja, obrazovanja te društvenog položaja. Zakonodavac diskriminacijom smatra i „uznemiravanje i spolno uznemiravanje“, ,poticanje na diskriminaciju, ako je počinjeno s namjerom“ (Europski sud pravde u Luxembourgu ne inzistira na postojanju namjere) i segregaciju kao ,prisilno i sustavno razdvajanje osoba“" po nekoj od diskriminirajućih osnova iz zakona. ${ }^{13}$

Temeljna načela koja se odnose na sprječavanje diskriminacije u području zapošljavanja i izbora zanimanja sadrži Konvencija br. 111. MOR-a iz 1958. Diskriminaciju definira (članak 1. st. 1.) kao: „svako pravljenje razlike, isključenje ili davanje prvenstva na temelju rase, boje kože, spola, vjere, političkog uvjerenja, nacionalnog ili socijalnog podrijetla, koje ima za posljedicu ukidanje ili narušavanje jednakosti u mogućnosti ili tretmanu pri zaposlenju ili zanimanju; svako drugo pravljenje razlike, isključenje ili davanje prvenstva koje ima za posljedicu ukidanje ili narušavanje jednakosti mogućnosti ili odnosa u zaposlenju i zanimanju koje utvrdi zainteresirana članica nakon savjetovanja s reprezentativnim organizacijama poslodavca i radnika, ako one postoje, i drugih odgovarajućih tijela“". ${ }^{14}$

Zaposleni mogu biti diskriminirani ako unatoč jednakim sposobnostima, obrazovanju i iskustvu primaju nižu plaću i nemaju mogućnost napredovanja. Diskriminaciju prema dobi teško je dokazivati. Diskriminacija i nezaposlenost utječu na socijalnu isključenost i ostvarivanje drugih ljudskih prava. Prema strategiji Europa 2020., na razini EU-a, Komisija radi na osmišljavanju i provedbi programa promicanja socijalnih inovacija za najranjivije, ponajprije stvaranjem inovativnih mogućnosti edukacije, osposobljavanja i zapošljavanja za zapostavljene zajednice, borbi protiv diskriminacije, primjerice, osobe $\mathrm{s}$ invaliditetom. ${ }^{15}$ Sloboda kretanja radnika prvobitno je obuhvaćala samo neposrednu i posrednu diskriminaciju na

13 Zakon o suzbijanju diskriminacije sadrži definicije diskriminacije ranjivih skupina. Tako: ,i propust da se osobama s invaliditetom, sukladno njihovim specifičnim potrebama, omogući: korištenje javno dostupnih resursa, sudjelovanje u javnom i društvenom životu, pristup radnom mjestu i odgovarajući uvjeti rada, prilagodbom infrastrukture i prostora, korištenjem opreme i na drugi način koji nije nerazmjeran teret za onoga tko je to dužan omogućiti“ (čl. 4. st. 2.), Narodne novine, br. 85/08.

14 Marinko, Učur i Sandra Laleta, Konvencije Međunarodne organizacije rada (Zagreb: TIM press, 2007.), 63.

15 Europa 2020., pristup 28. travnja 2020., https://mzo.hr/sites/default/files/migrated/europa-2020. pdf. 
temelju državljanstva u pogledu zapošljavanja, naknade i ostalih uvjeta rada. ${ }^{16}$

Ugovor EU-a navodi samo neposrednu diskriminaciju, ali Sud EU-a je sudskom praksom definirao i postavio kriterije za oba oblika diskriminacije u svrhu širenja slobodnoga kretanja radnika. Članak 45. UFEU-a (ex čl. 39. UEZ) u stavku 1. propisuje slobodno kretanje radnika, u stavku 2. zabranjuje svaku diskriminaciju u pogledu zapošljavanja, zarade (plaće i ostalih primanja) te ostalih uvjeta rada: „Takvo slobodno kretanje podrazumijeva ukidanje svake diskriminacije između radnika država članica na temelju državljanstva u pogledu zapošljavanja, zarade, te ostalih uvjeta rada". Zabranjena je diskriminacija na temelju državljanstva, na „državljanskoj pripadnosti različitoj od državljanstva države koja diskriminaciju provodi“ (čl. 45. st. 2. UFEU). ${ }^{17} \mathrm{U}$ presudi Komisija protiv Luksemburga utvrđena je neposredna diskriminacija, jer je Luksemburg propisao da učitelj može biti samo domaći državljanin, zbog specifične demografske situacije i nužnosti očuvanja nacionalnog identiteta.

Profesionalni sportaš je u subordiniranom položaju u odnosu na klub koji ga zapošljava i daje mu naknadu za razliku od samostalnih sportaša. Neposredna diskriminacija utvrđena je presudom Union Royale Belge des Societes de Football Association and Others protiv Jean-Marc Bosman (1995.), ${ }^{18}$ kada je radnik migrant stavljen u nepovoljniji ili lošiji položaj spram radnika državljanina te države članice. Belgijski nogometaš želio je prijeći iz belgijskog u francuski klub, što mu na temelju posebnih pravila nije bilo dopušteno. Sud EU-a potvrdio je kršenje slobode kretanja i zabrane diskriminacije iz članka 39. EUZ-a. Sud EU-a od predmeta Giovanni a Maria Sotgiu protiv Deutsche Bundespost $1974 .{ }^{19}$ utvrdio je da pravila koja se odnose na jednako postupanje zabranjuju ne samo otvorenu diskriminaciju utemeljenu na državnoj pripadnosti, nego i sve oblike prikrivene diskriminacije, koja preko drugih kriterija razlikovanja, ima iste učinke. Neka mjera može biti prividno neutralna, ali se njenom primjenom stvara nepovoljniji učinak za pripadnike određene skupine. U predmetu Wurttembergische Milchverwertung-Sudmilch AG protiv Salvatore Ugliola 1969. utvrđena je ništetnost odredbe njemačkoga Zakona o zaštiti radnih mjesta jer isključuje uračunavanje vojnih rokova europskih radnika koji rade u nekoj drugoj državi članici, čime neizravno diskriminira strance koji rade u Njemačkoj, a vojnu obvezu ispunjavaju u državi svog podrijetla.

16 Vidi Zlatan Meškić i Darko Samardžić, Pravo Evropske unije I (Sarajevo: TDP, GIZ GmbH, Otvoreni Regionalni Fond za jugoistočnu Evropu - Pravna reforma, 2012.), 343.

17 Hrvoje Arbutina, „Porezni izdaci u kontekstu presuda Europskog suda: Aspekti oporezivanja dohotka i dobiti, u: Zbornik radova s konferencije: Skrivena javna potrošnja i budućnost poreznih izdataka, ur. Vjekoslav Bratić i Martina Fabris (Zagreb: Institut za javne financije, 2012.), 199.

18 Odluka Suda Union royale belge des societes de football association ASBL and Others v. JeanMarc Bosman, br. EU C415/93 od 1995., I-3921., točka 73.

19 Meškić i Samardžić, Pravo Evropske unije I, 343; Predmet Giovanni a Maria Sotgiu v. Deutsche Bundespost br. ECR 152/73 od 1974. Vidi i Petar Bačić i Ivan Sarić, „Kratka studija aktivizma europskog suda kroz presude o slobodi kretanja radnika“, Zbornik radova Pravnog fakulteta $u$ Splitu 51, br. 1 (2014): 37. 


\section{FLEKSIGURNOST NA TRŽIŠTU RADA}

Fleksigurnost je složenica riječi: fleksibilnost i sigurnost. Na tržištu rada ta dva pojma imaju suprotno značenje pa postoji skeptičnost oko takvog vođenja tržišta rada. Fleksibilnost znači da poslodavci mogu lako zapošljavati i otpuštati radnika, odrediti rad na određeno vrijeme, na pola radnog vremena i sl. Sigurnost znači da radnici imaju sigurnost radnog mjesta, ${ }^{20}$ isplate plaće i dodataka. Fleksigurnost se ne temelji na sigurnosti zadržavanja postojećega radnog mjesta, već na sigurnosti zapošljavanja kod otkaza. Oružje su fleksigurnosti cjeloživotno obrazovanje, prekvalifikacija prema potrebi tržišta te visina naknade za nezaposlene (pri čemu osoba mora aktivno tražiti novi posao ili ući u program prekvalifikacije). Fleksigurnost se kao ideja pojavila osamdesetih godina 20. stoljeća, a primjenjuje se u Danskoj od devedesetih godina (koncept Rassmusenove vlade). Uz socijalni dijalog poslodavca, sindikata i države on je olakšao otpuštanje i zapošljavanje radnika te obvezno aktivno traženja posla za nezaposlene. Model počiva na tri stupa: fleksibilan standardni radni odnos uz nisku zaštitu zaposlenja, velika naknada za nezaposlene čime imaju dohodovnu sigurnost te aktivna politika zapošljavanja uz povećanje kvalificiranosti i aktiviranje nezaposlenih. Fleksibilnost i sigurnost nisu kontradiktorne, već komplementarne i međusobno podupiruće. ${ }^{21}$

Republika je Hrvatska u tranzicijskom razdoblju izgubila više od 800.000 radnih mjesta, dio je radnika prijevremeno umirovljen, dio se našao na birou ili potonuo u ,sivu“ ekonomiju. Fleksibilnost je bila nepoznata mjera. Zakon o radu i Zakon o zapošljavanju pokazali su se slabom zaštitom za radnike i za nezaposlene. Postojeći Zakon o radu je fleksibilniji, pruža srednji stupanj zaštite radnika, a definicija zaposlenosti i nezaposlenosti dijelom je usklađena sa strožim kriterijima MOR-a. ${ }^{22} \mathrm{U}$ mediteranskim i istočnoeuropskim državama ideja fleksigurnosti nije zaživjela jer sindikati ustraju na zadržavanju postojećih radnih mjesta. U RH naglašena je politika smanjenja razlika u segmentu zaštićenog i nezaštićenog zaposlenja. Predlaže se da se svi nestandardni oblici rada obuhvate Zakonom o radu da bi i ti radnici imali ista prava kao i oni koji imaju ugovor o radu. Socijalnu zaštitu nezaposlenih treba ojačati povećanjem naknada, aktivirati nezaposlene, pomagati u nalaženju posla (javne institucije za zapošljavanje), ulagati u cjeloživotno učenje kako bi se povećala zaposlenost i konkurentnost pojedinca na tržištu rada, osobito dugotrajno nezaposlenih i skupina koje se teže zapošljavaju. Međutim, neopravdana je pretjerana sigurnost u nekim segmentima tržišta rada. Rad „na crno“ zahtijeva kompleksnu politiku, koja se odnosi na njegovo uvođenje u zakonske okvire, osobito nelegalno samozaposlenih. Potrebno je pojednostavniti postupak registracije,

20 Strategija borbe protiv siromaštva i socijalne isključenosti u RH, 2014.-2020., pristup 25. travnja 2020., file:///I: /hr\%202020.pdf. Strateški plan ministarstva rada i mirovinskoga sustava, 2015.-2017., pristup 25. travnja 2020., http://www.mrms.hr/?s=strate\%C5\%A1ki+plan.

21 Saša Jurković, „Fleksigurnost - budućnost europskog zapošljavanja?“, pristup 25. travnja 2020., www.posao.hr. Alka Obadić, „The Danish flexicurity labour market policy concept“, EFZG working paper series br. 4 (2009): 1-15.

22 Sanja Crnković-Pozaić, Fleksigurnost: posljednja barikada u borbi za radničku sigurnost, pristup 25. travnja 2020., https://ider.media/arhiva/14699/. 
smanjiti poreze i obvezne doprinose i učiniti pristup legalnim instrumentima jeftinijim i bržim. Nužno je pojačati inspekcijski nadzor i njihovu ingerenciju.

Europska unija potiče članice da prihvate politiku fleksigurnosti uzimajući u obzir posebnosti svake od njih (u Lisabonskoj strategiji i strategiji Europa 2020.), kao pristup koji pomaže pri oblikovanju nacionalnih gospodarskih politika. Socijalni partneri slažu se da je tržištu rada potrebna fleksibilnost, međutim poslodavci i sindikati imaju različita stajališta o načinima njezina dostizanja. ${ }^{23}$ Državni intervencionizam u području radnih odnosa smatra se nepoželjnim rješenjem koje ne daje odgovore u krizi. Jača ideja deregulacije i fleksibilizacije. Klasični koncept radnog odnosa i radnika 20. stoljeća iščezava. Uvode se prihvate dosada nepoznatih fleksibilnih oblika zapošljavanja, jednostavniji postupak otpuštanja i zapošljavanja radnika uz novi sustav socijalne sigurnosti. Fleksibilna politika tržišta rada i aktivna politika zapošljavanja zahtijevaju pažljiv izbor ekonomsko-socijalnih mjera i koordinaciju njihove primjene. Fleksibilizacija je u svojoj početnoj etapi, sedamdesetih i osamdesetih godina 20. stoljeća, bila povezana s ekonomskim neoliberalizmom kao odgovorom na rast cijene energenata, inflacije, vanjska zaduženja i sl. Ona je dijelom odgovor poslodavaca na jačanje sindikata. Iako je ona danas drukčija, povezanost s neoliberalizmom utječe da su sindikati uglavnom njeni protivnici. Privremeni i povremeni rad takav su rad pri kojem je zaposlenost uvjetovana i prijelazna, izravno povezana $\mathrm{s}$ realnom potrebom zapošljavanja $\mathrm{u}$ proizvodnji. Netipični oblici rada i zapošljavanja znače sve oblike zapošljavanja koji odudaraju od tradicionalnog koncepta ugovora o radu na neodređeno vrijeme. Deregulacija znači zahtjev za brisanjem određenih instituta i poglavlja postojeće radnopravne regulative. ${ }^{24}$ Mihajlović navodi najčešće fleksibilne forme zapošljavanja: zapošljavanje sa skraćenim radnim vremenom; rad od kuće; povremeno i privremeno angažiranje; samozapošljavanje u različitim inačicama (individualno privređivanje, individualno pružanje usluga, timsko angažiranje, zadružni oblik privređivanja itd.), rad preko vikenda te radnike za pomoć u kući. ${ }^{25}$

Zagovornici fleksibilizacije ukazuju kako je odavno zaključeno da, za razliku od EU-a, SAD, Kina i Japan imaju produktivniju radnu snagu, čemu pridonose i uspostavljena načela fleksibilnosti na njihovim tržištima rada. ${ }^{26}$

Različite su definicije, vrste i oblici fleksibilnosti, npr. fleksibilnost radnog vremena, zaposlenja, plaća i organizacije rada ${ }^{27}$ vanjska, unutarnja, numerička i funkcionalna fleksibilnost. ${ }^{28} \mathrm{U}$ radnom se pravu spominje: unutarnja (fleksibilnost

23 Korjenić, Globalizacija i tržište rada, 29.

24 Vidi: Viktor Gotovac, „Radno pravo za 21. stoljeće: mitovi o fleksibilizaciji“, Financijska teorija i praksa 27, br. 4 (2003): 418-424; Korjenić, Globalizacija i tržište rada, 29.

25 Paraskeva Mihajlović, „Fleksibilne forme zapošljavanja u funkciji stvaranja uslova za veće zapošljavanje“, Pravni život 50, br. 452/10 (2001): 578.

26 Korjenić, Globalizacija i tržište rada, 29.

27 Vidi: Joe Lowther, „Fleksibilnost radne snage i uloga hrvatskih socijalnih partnera u njezinu povećanju“, Financijska teorija i praksa 27; Goran Loje, „Fleksibilizacija tržišta rada“, Pravo i porezi 17, br. 10 (2008): 43.

28 Sandrine Cases i Alena Nesporova, ur., Fleksigurnost: Relevantan pristup za srednju i istočnu Europu (Zagreb: TIM press, 2007.), 18. 
radnog vremena s prekovremenim i skraćenim radnim vremenom), vanjska (postupak prijama i otpuštanja zaposlenika), organizacijska (suradnja poslodavaca, outsourcing) i zemljopisna fleksibilnost.

EU zagovara globalna ljudska prava i uspostavila je niz instrumenata u tu svrhu. Fleksibilnost se pojavila kao mogući odgovor na ekonomsku krizu, nezaposlenost, pad potražnje za radnom snagom, potrebom za većom prilagodljivosti tržištu rada. Radni su odnosi okosnica gospodarstvenog sustava, a reforme moraju polaziti od radnoga zakonodavstva. Fleksibilnost tržišta rada krenula od fleksibilizacije radnih odnosa kako bi se olakšalo prilagođavanje novim tržišnim uvjetima. To zahtijeva prilagođavanje zaposlenika, povećanje fleksibilnosti u radnom zakonodavstvu i volju zaposlenika da se tome prilagode.

Mnogi vjeruju da kolektivno pregovaranje koči fleksibilnost rada, no kod dobrog pregovaranja ono može povećati fleksibilnost. ${ }^{29}$ Da bi se izbjegli nedostatci fleksibilizacije, važno je provoditi mjere u korist poslodavaca i zaposlenih. Ona zaposlenima jamči veću sigurnost (engl. flexicurity - fleksigurnost). Pojam fleksigurnost potječe iz nizozemskoga prava (Wet Flexibiliteit en Zekerheid iz 1999.), on nudi privremenim zaposlenicima mogućnost stalnog zaposlenja putem agencija nakon dvije godine rada i kombinira fleksibilni raspored zaposlenih sa sigurnošću zapošljavanja. Ravnoteža je delikatna, poslodavci i radnici traže win-win strategije i rješenja na obostranu korist. ${ }^{30}$

„Koncept fleksigurnosti je zapravo strateška politika održavanja s jedne strane fleksibilnosti na tržištu rada i odnosa na tržištu rada i s druge strane sigurnosti u zapošljavanju i prihodima pojedinca. U posljednjih dvadesetak godina većina članica EU izmijenila je zakonsku regulativu u vezi s definiranjem atipičnih oblika rada uz određene različitosti od države do države, ali s istim ciljem: povećati fleksibilnost tržišta rada kako bi se povećala učestalost otvaranja novih radnih mjesta uz istovremeno izjednačavanje i poboljšavanje uvjeta rada radnika zaposlenih na osnovi spomenutih atipičnih ugovora o radu“. 31

\section{NEZAPOSLENOST}

Zaposlenost se naziva i ,ljepilom koje drži naše društvo na okupu“, 32 a nezaposlenost je njezina suprotnost. Niz ekonomskih, socijalnih i političkih pitanja ovisi o učinkovitosti politike tržišta rada, npr. porast zaposlenosti smanjuje

29 Loje, Fleksibilizacija tržišta rada, 42-43.

30 Senad Jašarević, „Radni odnos - tendencije u svijetu i u Srbiji“, Aktualnosti građanskog $i$ trgovačkog zakonodavstva i pravne prakse br. 12 (2014): 303. „Mere fleksigurnosti mogu se uočiti u različitim nacionalnim i međunarodnim sistemima upravljanja: u Lisabonskoj strategiji Evropske unije (EU) i u Globalnoj agendi za zapošljavanje MOR-a, u sistemima koji se trenutno koriste u Austriji i Belgiji i u Skandinavskim zemljama. U svakoj zemlji stavlja se različit naglasak na vrste fleksibilizacije i sigurnosti jer su oba koncepta višedimenzionalna.“ Vidi i Fleksigurnost, 20.

31 Korjenić, Globalizacija i tržište rada, 38-39.

32 Nenad Starc, ur., Siromaštvo, nezaposlenost i socijalna isključenost (Zagreb: Program UN za razvoj, 2006.), 38. 
socijalne troškove države prema izdržavanom dijelu populacije. Prema Istraživanju o radnoj snazi (EU LFS) zaposlene osobe su one starije od 15 godina, koje su u referentnom tjednu obavljale, barem jedan sat tjedno, određeni rad za plaću, dobit ili obiteljsku korist kao i privremeno odsutni zaposleni, npr. zbog bolesti, godišnjeg odmora, radnih sporova, obrazovanja ili osposobljavanja. ${ }^{33}$ International Labour Organisation (ILO) definira nezaposlene kao osobe starije od dobne granice određene za mjerenje ekonomski aktivnog stanovništva (u RH 15 godina) koje su u promatranom razdoblju bile: bez posla, tj. nisu imale plaćeno zaposlenje ili bile samozaposlene kako predviđa međunarodna definicija zaposlenosti te su trenutačno na raspolaganju za posao, tj. bile spremne započeti s poslom u svakom trenutku $\mathrm{u}$ referentnom razdoblju, tražile posao i poduzimale korake radi pronalaženja zaposlenja. Nezaposlenost podrazumijeva određeni broj radnika koji želi raditi uz uobičajenu plaću prema kvalifikaciji, ali ne mogu naći posao. ${ }^{34}$ Kriteriji moraju biti zadovoljeni istodobno. Osobe koje su našle posao, ali nisu započele s radom klasificiraju se kao nezaposlene jer su dio neiskorištenoga radnog resursa. ${ }^{35}$ Članak 7. Zakona o posredovanju pri zapošljavanju i pravima za vrijeme nezaposlenosti RH definira nezaposlenost. ${ }^{36}$

Nezaposlenost se javlja od najstarijih vremena, pojavom najamnog rada. Od 19. stoljeća istražuje se znanstveno. Cilj je makroekonomske politike borba protiv nezaposlenosti. Ona može biti posljedica: uobičajenih kratkotrajnih prekida zbog promjene radnog mjesta, sezonskih fluktuacija tržišta rada, tehnoloških usavršavanja ili preusmjeravanja proizvodnje, poslovnih ciklusa i poremećaja na tržištu rada zbog kojih se smanjuje potražnja radnika. Ona raste u doba političkih i gospodarskih kriza, tehnoloških promjena, prirodnih katastrofa i ratova. ${ }^{37}$ Razlikuje se sezonska, frikcijska, strukturalna i ciklička nezaposlenost. Frikcijska je nezaposlenost kratkoročna, privremena nezaposlenost koja nastaje kretanjem ljudi u regijama ili radnim mjestima. Strukturnu nezaposlenost uzrokuje neravnoteža u strukturi ponude i potražnje za radom. ${ }^{38}$ Cikličku nezaposlenost uzrokuju poslovni ciklusi i povremeni poremećaji. ${ }^{39}$ Tzv., prikrivena nezaposlenost je nedostatna iskorištenost radne snage među zaposlenima. To je osobito dio socijalističke ideje pune zaposlenosti uz brojna nepotrebna radna mjesta. Tzv., normalna nezaposlenost uključuje sezonsku i frikcijsku nezaposlenost. Sezonska je posljedica varijacija gospodarskog procesa

33 Employment - annual statistics, Eurostat, pristup 19. siječnja 2017., http://ec.europa.eu/ eurostat/statistics-explained/index.php/Employment_statistics.

34 Đuro Benić, Osnove ekonomije, 3. izd. (Zagreb: Školska knjiga, 2001.), 525.

35 Psihološki aspekti nezaposlenosti, Zbornik radova XII. ljetne škole studenata i nastavnika Odsjeka za psihologiju Filozofskog fakulteta u Zagrebu (Silba: Filozofski fakultet u Zagrebu, 2002.).

36 Zakon o posredovanju pri zapošljavanju i pravima za vrijeme nezaposlenosti RH, Narodne novine, br. 38/02. Vlado Puljiz et al., Socijalna politika Hrvatske (Zagreb: Pravni fakultet u Zagrebu, 2008.), 164-165.

37 Predrag Bejaković, „Nezaposlenost“, Financijska teorija i praksa 27 (2003): 659-661.

38 Željko Mrnjavac, „Razlikovanje tipa nezaposlenosti - neizvodljiva misija“, Ekonomska misao $i$ praksa 11, br. 2 (2002): 221.

39 Đuro Benić, „Povijest razvoja teorije o odnosu između inflacije i nezaposlenosti“, Ekonomska misao i praksa 2, (2014): 411. 
u nekim djelatnostima uvjetovanim klimatskim, tradicionalnim ili institucionalnim uvjetima, uz uvjet da se ta razdoblja ne mogu premostiti proizvodnjom zaliha ili preraspodjelom radnog vremena. ${ }^{40}$ Nezaposleni troše znatnu količinu vremena i energije na traženje posla i osiguravanje egzistencije. ${ }^{41}$ Državna vlast utječe na smanjenje nezaposlenosti. Kod frikcijske nezaposlenosti ona daje informacije o poslovima, dok kod strukturne koja pogađa skupine prema stupnju obrazovanja uvodi obrazovne subvencije, prekvalifikacije i sl. Kod cikličke nezaposlenosti i nedostatka potražnje radne snage provodi fiskalnu, monetarnu ili politiku ponude te subvencionira nadnice i kredite za zapošljavanje. Ipak, nijedna zemlja tržišnoga gospodarstva ne može imati punu zaposlenost. ${ }^{42} \mathrm{U}$ RH je naglašen sezonski karakter nezaposlenosti i njezin rast od kolovoza do siječnja.

Nezaposlenost u RH statistički prati Državni zavod za statistiku, uredi i službe zapošljavanja registriraju nezaposlene te poslodavcima daju podatke o raspoloživim radnicima. Nusproizvod službe je evidencija nezaposlenih i anketa radne snage kao izvor statističkih podataka. „Siva“ ekonomija prikriva pravi broj nezaposlenih (Zavod za 2009. daje prosjek 263.000 nezaposlenih, a anketa 160.000). Podatci u RH za proteklih deset godina ukazuju na rast nezaposlenosti tijekom globalne financijske krize. Nepovoljan je i trend smanjivanja broja stanovnika pa i radne snage. Prema popisu stanovnika 2001. iznosio je 4.437.460, a 2011. 4.284.460 (pad za 152.571 ili $3,4 \%){ }^{43}$ Problem nezaposlenosti egzistencijalni je problem pojedinca, ali i društva u cjelini.

„Siva“ ekonomija je ekonomska aktivnost pojedinca, skupine ili organizacije uz izbjegavanje zakonskih propisa. Ona postoji i u razvijenim zemljama, iako u različitim omjerima.

Stavljanjem u odnos nezaposlenih i radne snage dobivamo realnu sliku nezaposlenosti. Od 2008. raste broj nezaposlenih kao posljedica svjetske gospodarske krize. Do tada je bilježen blagi pad, ali nikada ispod $9 \%$. Najveći broj nezaposlenih osoba registriran je 2013. (345.100). Najveća razlika između anketne i registrirane stope nezaposlenosti zabilježena je 2009. (5,8 \%), a najmanja 2014. (2,3\%). Dijelom je ta razlika rezultat razlika u definiciji nezaposlene osobe. Prednost su mjerenja mjesečni pokazatelji nezaposlenosti, a podatci iz registra i ankete omogućuju precizniju usporedbu jer pokrivaju čitavo tržište rada.

Hrvatski Zavod za zapošljavanje (dalje: HZZ) ustrojen je Zakonom o posredovanju pri zapošljavanju i pravima za vrijeme nezaposlenosti ${ }^{44}$ kao javna

40 Petar Tomašić, Nezaposlenost u tranzicijskoj Hrvatskoj pod socijalno-etičkim vidom (Zagreb: Kršćanska sadašnjost, 2010.), 47.

41 Puljiz et al., Socijalna politika Hrvatske, 164-165.

42 Tomašić, Nezaposlenost u tranzicijskoj Hrvatskoj pod socijalno-etičkim vidom, 48, 53-56.

43 Ines Kersan-Škabić, Ekonomija Europske unije (Pula: Sveučilište Jurja Dobrile, Odjel za ekonomiju i turizam „Dr. Mijo Mirković“, 2012.), 138. „Siva“ ekonomija je ekonomska aktivnost pojedinca, skupine ili organizacije uz izbjegavanje zakonskih propisa. Ona postoji i u razvijenim zemljama, iako u različitim omjerima. Marija Bušelić, Tržište rada: teorijski pristup (Pula: Fakultet ekonomije i turizma „Dr. Mijo Mirković“", 2014.), 101; Zvonimir Galić, Nezaposlenost, traženje posla i zapošljavanje: longitudinalna analiza psiholoških aspekata doktorska disertacija (Zagreb: Filozofski fakultet, 2008.), 3.

44 Zakon o posredovanju pri zapošljavanju i pravima za vrijeme nezaposlenosti, Narodne novine, 
ustanova u vlasništvu RH sa zadaćom rješavanja pitanja povezanih sa zapošljavanjem i nezaposlenosti, posreduje pri zapošljavanju, organizira profesionalno usmjerava i obrazuje te materijalno osigurava nezaposlene. HZZ obuhvaća mrežu s 22 područna ureda i 99 ispostava..$^{45} \mathrm{HZZ}$ evidentira nezaposlene prema članku 10. Zakona. To je osoba sposobna ili djelomično sposobna za rad, u dobi od 15 do 65 godina koja nije u radnom odnosu uz preciziranje iznimki. Državni zavod za statistiku u RH od 1996. provodi tjednu anketu radne snage i nezaposlenih prema uzoru na anketu Statističkog ureda Europske zajednice (Eurostat) čiji se rezultati objavljuju tromjesečno.

S makrostajališta nezaposlenost je gubitak za proizvodnju, ali i gubitak najkvalitetnijih, obrazovanih radnika koji su prisiljeni tražiti posao izvan zemlje. Ulaskom RH u EU, HZZ je postao dio Europske mreže javnih službi za zapošljavanje EURES za zapošljavanje država članica europskoga gospodarskog prostora i Švicarske. ${ }^{46}$ U HZZ-u djeluju četiri Migracijska informacijska centra u područnim uredima Zagreb, Osijek, Rijeka i Split. Oni daju informacije i pružaju savjetodavne usluge o zapošljavanu, životnim uvjetima, vizama, školovanju u inozemstvu, imigracijskim programima, pravima i zaštiti imigranata, spajanju obitelji u državama te o mogućnostima dolaska stranaca ili povratnika u RH. HZZ je koristio financijsku i tehničku pomoć iz IPA programa (Instrument for Pre-Accession Assistance) 2007.2013., koji je pomagao državama kandidatkinjama i potencijalnim kandidatima u usklađivanju i provedbi pravne stečevine EU-a, kao i pripremama za korištenje strukturnih fondova EU-a. Stupanjem u EU, RH je dobila pristup široj i izdašnijoj „lepezi” potprograma za financiranje.

Europska komisija je 30. listopada 2014. usvojila Sporazum o partnerstvu između RH i Europske komisije za korištenje EU-ovih strukturnih i investicijskih fondova (ESI) za rast i radna mjesta od 2014. do 2020. Partnerski sporazum propisuje način na koji će RH ispuniti zajedničke ciljeve strategije Europa 2020. uz sredstva iz proračuna EU-a. U tom je razdoblju RH iz ESI fondova na raspolaganju imala 10,676 milijardi eura. ${ }^{47}$

Nezaposlenost uzrokuje ponajprije rasipanje resursa, a time i niz teškoća za cjelokupno gospodarstvo. U RH su uzroci nezaposlenosti Domovinski rat, tranzicija i globalizacija. Nakon rata su veliki izdatci bili potrebni za proces obnove i razminiranja koji još do danas nisu potpuno dovršeni. ${ }^{48}$ Nezaposlenost je u RH posljedica strukturnih promjena gospodarstva, likvidacija i stečaja

br. 12/13., pročišćeni tekst.

45 Hrvatski zavod za zapošljavanje, pristup 15. svibnja 2020., www.hzz.hr. Čl. 10. Zakona o posredovanju pri zapošljavanju i pravima za vrijeme nezaposlenosti, Narodne novine, br. 12/13.; Zakon o izmjenama i dopunama Zakona o posredovanju pri zapošljavanju i pravima za vrijeme nezaposlenosti, Narodne novine, br. 25/12.

46 Kristina Mazalin i Maja Parmač Kovačić, „Odrednice percipirane zapošljivosti studenata“, Društvena istraživanja 24, br. 4 (2015), https://hrcak.srce.hr/file/166401/.

47 Hrvatski zavod za zapošljavanje, pristup 15. svibnja 2020., http://www.hzz.hr/; Europski strukturni i investicijski fondovi, 2014.-2020., pristup 18. svibnja 2020., www.prvikorak.eu/ eu-fondovi-2014-2020.aspx.

48 Ivo Družić, „Tržišno restrukturiranje i privatizacija hrvatskoga gospodarstva“, u: Privatizacija hrvatskog gospodarstva, ur. Barić, Vinko et al. (Zagreb: Ekonomski fakultet Zagreb, Politička kultura, 2003.), 137-173. 
poduzeća, otpuštanja zaposlenih, smanjenih mogućnosti zapošljavanja, prostorne i profesionalne neusklađenosti ponude i potražnje rada. ${ }^{49}$ Država je trpjela izdatke za socijalnu skrb izbjeglica i prognanika, za obnovu, obranu i dr. Drugi je razlog rasta nezaposlenosti u tranziciji neravnomjeran odnos između dinamike zatvaranja radnih mjesta u danas javnom sektoru i dinamike otvaranja radnih mjesta u novoosnovanim privatnim poduzećima. ${ }^{50}$

$\mathrm{Na}$ nezaposlenost je bitno utjecalo nasljeđe socijalizma i, tzv. društveno vlasništvo na gospodarskim subjektima koje nije djelovalo na tržišnim načelima, već je trebalo povećati motiviranost radnika za njihov uspješan rad. ${ }^{51}$ Stoga je osamostaljenjem RH i tranzicijom prijelaza na tržišno gospodarstvo došlo do problema i u obliku nezaposlenosti. ${ }^{52}$ Tranzicija (prijelaz) označava, tzv. tranzicijske države koje su iz planskog prelazile u tržišno gospodarstvo i parlamentarnu demokraciju. ${ }^{53}$ Ekonomisti većinom definiraju privatizaciju kao prijenos ukupnog vlasništva, ili većeg dijela vlasništva, javnog (ili društvenog) sektora, privatnim osobama. ${ }^{54}$ Društvena poduzeća postaju dionička društva ili društva ograničene odgovornosti s poznatim titularom vlasništva, osim subjekata koji imaju stratešku važnost za RH. ${ }^{55} \mathrm{U}$ tom je procesu bilo i loših pojava te su neke tvrtke propale. ${ }^{56}$ Gubitak radnih mjesta trebao se kompenzirati otvaranjem novih u malim i srednjim poduzećima $u$ privatnom vlasništvu, ali to se nije ostvarilo. Uz osnovni razlog, Domovinski rat, bila je nepovoljna i makroekonomska klima (visoka cijena kapitala, nedobivanje kredita, fiskalno opterećenje, državna birokracija, visoki početni i minimalni troškovi proizvodnje i usluga, visoka ili preniska cijena rada). ${ }^{57}$ Nezaposleni su imali mnoga prava (zdravstveno osiguranje, socijalnu pomoć, dječji doplatak, oslobađanje od pristojbi i dr.). Učestao je rad „na crno“ pri čemu su „nezaposleni“ čuvali svoj status i prava kao negativno obilježje tranzicije koje je mogao voditi korupciji, lobiranju, povećanju socijalnih razlika u društvu i smanjenju proračunskih prihoda. ${ }^{58}$

Globalizacija je važan segment svijeta novoga tisućljeća. Ona je proces jačanja međusobne povezanosti ljudi na Zemlji kroz postupno ukidanje ograničenja kretanja ljudi, ideja, kultura, roba, usluga, rast međunarodne trgovine i stvaranje velikoga

49 Katarina Ott, ur., Javne financije u Hrvatskoj, 3. izd. (Zagreb: Institut za javne financije, 2007.), 121.

50 Marinko Škare, „Nezaposlenost u Hrvatskoj i determinante potražnje za radom“, Revija za socijalnu politiku 8, br. 1 (2001), http://hrcak.srce.hr/file/47371.

51 Družić, Tržišno restrukturiranje i privatizacija hrvatskoga gospodarstva, 137-173.

52 Anton Vukelić, Anomija pojedinih socijalnih grupa suvremenog hrvatskog društva: doktorska disertacija (Zagreb: Pravni fakultet, 2002.), 125.

53 Ivo Družić, Razvoj i tranzicija hrvatskog gospodarstva (Zagreb: HAZU, 1997.).

54 Pero Jurković et al., (ur.), Poslovni rječnik (Zagreb: Masmedia, 1991.), pojam Privatizacija, 395.

55 Miroslav Gregurek, „Stupanj i učinci privatizacije u Hrvatskoj“, Ekonomski pregled 52, br. 1-2 (2001): 155-188.

56 Družić, „Tržišno restrukturiranje i privatizacija hrvatskoga gospodarstva“, 137-173.

57 Škare, „Nezaposlenost u Hrvatskoj i determinante potražnje za radom“. Revija za socijalnu politiku, 8, br. 1 (2001): 19-34.

58 Bejaković, Predrag. „Nezaposlenost“. Financijska teorija i praksa 27, br. 4 (2003): 659-661. 
svjetskog tržišta. Globalizacija je početno imala obećavajući potencijal rješenja nejednakosti i siromaštva, ali ona na tržištu rada utječe na selidbu industrija koje zahtijevaju visokoobrazovanu radnu snagu u države gdje nje ima, dok se ostale industrije, npr. tekstilna, sele u države, tzv. „trećeg svijeta“ koje imaju jeftinu i mnogobrojnu radnu snagu. ${ }^{59}$ Međunarodni sporazumi o carinama i trgovini u sklopu WTO-a i OECD-a jačaju globalne integracije i nove gospodarske zone, utječu na mobilnost kapitala, ali i radne snage kao i njezinu nezaposlenost. ${ }^{60}$

\section{POLITIKA ZAPOŠLJAVANJA NA TRŽIŠTU RADA}

Zapošljavanje je važno pitanje za pojedinca i zajednicu. Ono obuhvaća materijalne i nematerijalne aspekte, jer je plaća osnova za osiguranje egzistencijalnih potreba pojedinca i obitelji te utječe na razvoj njegova socijalnog i kulturnog života i interakcije. Dugotrajna nezaposlenost uzrok je siromaštva. Zato država mora imati utvrđenu politiku zapošljavanja. Politiku zapošljavanja određuju i potrebe poslodavaca za radnom snagom. Gospodarska kriza, stagnacija i recesija stvara raskorak između potražnje i ponude radne snage, između socijalnih i ekonomskih kriterija u tržišnom gospodarstvu. Propast socijalističke ekonomije dovela je do nezaposlenosti i potrebe formiranja suvremenoga tržišta rada. ${ }^{61}$

Razlikuju se aktivne i pasivne mjere u politici zapošljavanja. Pasivne mjere osiguravaju materijalnu zaštitu, dok aktivne povećavaju zapošljavanje nezaposlenih. ${ }^{62}$ Pasivne su mjere kratkoročne i nisu trajno rješenje i zahtijevaju financijsku potporu države. Aktivne mjere obuhvaćaju prekvalifikaciju, dokvalifikaciju, osposobljavanje, doškolovanje i sl., čime se povećava proizvodnja, a time i potražnja za radnom snagom. RH putem javnih zavoda za zapošljavanje provodi aktivne mjere, namijenjene isključivo nezaposlenim osobama s otežanim pristupom tržištu rada, radi lakšeg i bržeg zapošljavanja. Uvedene su i aktivne mjere, npr. sufinanciranje zapošljavanja i javni radovi. U najnepovoljnijem su položaju mladi kao stariji, osobe s invaliditetom, dugotrajno nezaposleni, žene i nekvalificirani radnici. Aktivnim se mjerama stječe pre/kvalifikacija, dokvalifikacija i stručno osposobljavanje, poslodavci dobivaju potporu za zapošljavanje određenih skupina, a potiče se i samozapošljavanje. ${ }^{63}$ Država nadzire aktivne mjere politike zapošljavanja.

Uložena se sredstva vraćaju u proračun uplatom doprinosa, poreza, prireza,

59 Statistička analiza nezaposlenosti u Republici Hrvatskoj 2000.-2010. (Zagreb: Hrvatski zavod za zapošljavanje, 2012.), http://e-lib.efst.hr/2012/7981260.pdf.

60 Vojmir Franičević i Vlado Puljiz, ur., Rad u Hrvatskoj: pred izazovima budućnosti (Zagreb: Centar za demokraciju i pravo Miko Tripalo, Pravni fakultet Sveučilišta u Zagrebu, 2009.); Korjenić, Globalizacija i tržište rada, 8.

61 Strateški plan ministarstva rada i mirovinskoga sustava 2013.-2015., pristup 29. travnja 2020., https://vlada.gov.hr/UserDocsImages//ZPPI/Strategije\%20-\%20OGP/rad\%20i\%20 mirovinski\%20sustav//strateski-plan-2013-2015.

62 Alka Obadić i Ela Majić, „Analiza strukture nezaposlenih visokoobrazovanih osoba u Republici Hrvatskoj i mjere za njezino smanjenje“, Poslovna izvrsnost 7, br. 2 (2013): 103-123, https:// hrcak.srce.hr/file/166401.

63 Mjere aktivne politike zapošljavanja, pristup 5. veljače 2020., http://mjere.hr/. 
manjih izdvajanja za socijalne naknade, povećanjem kupovne moći. Nezaposleni se mjerama aktivne politike zapošljavanja socijalno uključuju te stječu dodatne kompetencije, znanja i vještine bitne za konkurentniji osobni položaj na tržištu rada. Ipak, mjere aktivne politike zapošljavanja ne mogu zamijeniti pravo otvaranje radnih mjesta na temelju gospodarskog rasta. Cilj im je u krizi obuhvatiti što veći broj ljudi, kako bi barem neko vrijeme bili u radnom procesu ili obrazovanju koje će im omogućiti konkurentnost $\mathrm{u}$ zapošljavanju. ${ }^{64}$

HZZ, kao provedbeno tijelo Ministarstva rada i mirovinskoga sustava, vodilo je važnu mjeru stručnog osposobljavanja za rad bez zasnivanja radnog odnosa. ${ }^{65}$ Aktivna politika zapošljavanja prioriteta je u državama članicama EU-a, integrirana u ciljeve Strategije Europa 2020., a jačanje njezine učinkovitosti i dosega na tržištu rada jedna je od preporuka Europske komisije unutar Europskog semestra za RH.

Pritisak aktivne radne snage na tržištu radi smanjenja nezaposlenosti može se ostvariti i smanjivanjem gornje dobne granice zaposlenosti, pa zaposlenici stariji od 65 godina moraju otići u mirovinu i osloboditi radna mjesta. Pritom se postavlja pitanje opravdanosti, osim u zanimanjima koja su nepotrebna ili su fizički i psihički iscrpljujuća. ${ }^{66}$ Snižavanje dobne granice dovodi i do većeg opterećenja plaća zaposlenih izdvajanjem u mirovinske fondove, zapošljavanja umirovljenika u drugim formama i njihovim radom „na crno“.

Pasivne mjere osim socijalne sigurnosti imaju ekonomsku ulogu. Osoba nije prisiljena prihvatiti posao koji ne odgovara njenim sposobnostima jer će odgovarajućim poslom ostvariti bolju proizvodnost i bolje pridonijeti gospodarstvu. ${ }^{67}$ Praćenje, analiza, predviđanje potreba i planiranje tržišta rada za pojedina zanimanja temelj su za izradu upisnih kvota u obrazovanju i stipendiranju polaznika. Primjena pasivnih politika na neki način stimulira nezaposlene da budu dulje vrijeme neaktivni.

Pasivna politika samo privremeno smanjuje ponudu na tržištu rada. RH pratiti smjernice i preporuke EU-a, a fokus je mjera integracija stanovništva u svijet rada i društveni život te jačanje odgovornosti za vlastiti materijalni i socijalni život. Fleksigurnost stavlja naglasak na sustav obrazovanja i cjeloživotno obrazovanje. Europska komisija, osobito Barroso, Špidla i drugi njezini članovi promicali su takav pristup te su inicirali tripartitni socijalni sastanak na vrhu na temu fleksigurnosti u listopadu 2006., pokrećući proces utvrđivanja općih načela fleksigurnosti za nacionalne politike zapošljavanja. ${ }^{68}$ Europska komisija donijela

64 Marija Bušelić, Mjere za poticanje zapošljavanja u Republici Hrvatskoj: doktorska disertacija, (Zagreb: Ekonomski fakultet, 2001.), 41. Mjere aktivne politike zapošljavanja, pristup 26. svibnja 2020., https://vlada.gov.hr/rezultati-pretrazivanja/49?pojam=mjere+politike+zapo\%C 5\%A1ljavanja.

65 Hrvatski zavod za zapošljavanje, pristup 25. svibnja 2020., www.hzz.hr.

66 Smjernice za razvoj i provedbu aktivne politike zapošljavanja u Republici Hrvatskoj za razdoblje 2015.-2017., pristup 25. svibnja 2020., www.mrms.hr/wp-content/uploads/2015/02/ smjernica-apz.pdf, vidi i Crnković-Pozaić, Tržište rada u Hrvatskoj.

67 Predrag P. Bejaković, „Materijalno-pravna zaštita nezaposlenih u Hrvatskoj i u odabranim zemljama“, Revija za socijalnu politiku 4, br. 3 (1997), www.rsp.hr/ojs2/index.php/rsp/article/ view/381/385.

68 Ovaj koncept "fleksigurnosti" način je osiguranja da poslodavci i radnici imaju fleksibilnost, ali 
je akt „Prema zajedničkim načelima fleksigurnosti“, brojnija i bolja radna mjesta putem fleksibilnosti i sigurnosti kao europski model fleksigurnosti koji kombinira fleksibilizaciju tržišta rada s visokom razinom socijalne sigurnosti. ${ }^{69}$ Fleksigurnost predviđa lakše zapošljavanje i otpuštanje, uz velika prava nezaposlenih koji će financijski osigurani i motivirani stalno aktivno tražiti posao. RH je ulaskom u EU stekla pravo na sredstva iz njenih fondova, npr. iz Europskog socijalnog fonda, otvoreno je tržišta rada EU-a hrvatskim građanima što je zanimljivo mladima, npr. putem EURES mreže za traženje zaposlenja u kojoj su i savjetnici iz RH. ${ }^{70}$ Građani RH dobili su pravo korištenja europske zdravstvene iskaznice i korištenja zdravstvenih usluga na području EU-a i pri privremenom boravku u inozemstvu. EU podupire programe država članica u politici zapošljavanja mladih postavljanjem ciljeva i preporuka u sklopu Strategije Europa 2020. i pružanjem financijske potpore kroz programe Europskog socijalnog fonda. ${ }^{71}$ Ulaskom u EU RH postaje zanimljivija za strana ulaganja, a time i je moguć i porast zaposlenosti. EU je kao cilj do 2020. istaknula postizanje $75 \%$ zaposlenosti stanovništva u dobi između 20. do 64 . godine te smanjivanje broja osoba u riziku od siromaštva za 20 milijuna. ${ }^{72} \mathrm{~S}$ druge strane, ulaskom u EU RH se morala odreći sporazuma o slobodnoj trgovini u regiji - CEFTA-e, što se negativno odrazilo na razmjenu s BiH-om i Srbijom, a time i na zaposlenost. $^{73}$

Djelomičan pesimistični pogled na članstvo u EU treba postupno prevladati, osobito rastom životnog standarda, na koji utječe povećana mogućnost zapošljavanja u EU čemu mora pridonijeti zalaganje i rad političara, ${ }^{74}$ ali i pravnika, znanstvenika uopće i gospodarstvenika koji će razraditi kvalitetnu strategiju razvoja i projekte. Početna povećanja izdvajanja nastala ulaskom u EU dugoročno će donijeti koristi i pri zapošljavanju. ${ }^{75} \mathrm{RH}$ i dalje bilježi visoku stopu nezaposlenosti u europskom kontekstu, rekordno nizak angažman radne snage praćen visokim postotcima „sive“ ekonomije ili rada „na crno“, visoku nezaposlenost mladih, recesiju te visoku regionalnu nejednakost nezaposlenosti. Veliki gubitak zaposlenosti uzrokovali su ratna razaranja, tranzicija s netransparentnom privatizacijom i recesijska kretanja. Najugroženije skupine društva su mladi bez radnog iskustva. Prema podatcima Eurostata RH je bila na trećem mjestu po broju nezaposlenosti mladih u EU 2016. ${ }^{76}$

i potrebnu sigurnost (José Manuel Barroso, predsjednik, Bruxelles, 20. veljače 2006.).

69 Prema zajedničkim načelima fleksigurnosti COM 2007 (359) konačni tekst 27. lipnja 2007. https://eur-lex.europa.eu/legal-content/HR/TXT/?uri=legissum:c10159.

70 Radni odnosi u Republici Hrvatskoj nakon ulaska u Europsku uniju: zbornik radova (Zagreb: 2013.).

71 Zapošljavanje mladih nakon ulaska u EU, pristup 29. svibnja 2015., www.eukutak.info.

72 Europe 2020: A strategy for smart, sustainable and inclusive growth (COM(2010) 2020 final), 5 Eurostat, pristup 5. lipnja 2020., http://ec.europa.eu/eurostat/en/web/products-datasets/-/ UNE_RT_M Proračunski deficit, www.banka.hr/hrvatska/.

73 Deutsche Welle, pristup 2. svibnja 2020., www.dw.de/deutsche-bank-kratkoro\%C4\%8Dnonema-pozitivnog-u\%C4\%8Dinka-ulaska- hrvatske-u-eu/a-17868283.

74 Deutsche Welle.

75 Mrnjavac, Razlikovanje tipa nezaposlenosti - neizvodljiva misija, 104.

76 Zaposlenost-godišnja statistika, Eurostat, pristup 5. lipnja 2020., https://ec.europa.eu/eurostat/ statistics-explained/index.php?title=Employment_statistics/hr\#Dodatni_podaci_Eurostata. 


\section{ZAKLJUČAK}

RH ima nefleksibilno tržište rada koje sporo reagira na promjene, stvarajući dugotrajnu nezaposlenost i socijalnu isključenost. Tržište rada slabo je povezano s obrazovnim sustavom. Ulaskom u EU nužno je ojačati nove trendove u politici zapošljavanja. Osobito se ističe koncept fleksigurnosti kao fleksibilan odnos zapošljavanja i socijalne sigurnosti pri traženju zaposlenja, jasno uređene radne odnose, cjeloživotno učenje te aktivne mjere zapošljavanja. Hrvatska regulativa zapošljavanja još je formalno, ali i ne stvarno usklađena s politikom EU-a. Potrebno je stvoriti povoljniju makroekonomsku klimu, jednostavnije i stabilnije zakonske regulative te poticati investicije u profitabilne djelatnosti, koje neće biti samo uslužnoga karaktera, nego će stvarati novu vrijednost koja će ići u investicije. S druge strane, treba očuvati socijalnu sigurnost građana. Stoga treba imati jasnu viziju razvojnog puta, ciljeva i izazova, uz gospodarsku krizu i postojeću pandemiju bolesti COVID-19.

RH i dalje bilježi visoku stopu nezaposlenosti, rekordno nizak angažman radne snage uz visoki postotak, tzv. „sive“ ekonomije i rada „na crno“, nezaposlenost mladih, blagu recesiju te unutrašnju regionalnu nejednakost u nezaposlenosti. Veliki pad zaposlenosti uzrokovali su tranzicijski šok, ratna razaranja, netransparentna privatizacija i svjetska recesija. Dijelu građana ugrožena su socijalna prava neisplatom plaća ili doprinosa u mirovinske i zdravstvene fondove. Programi važni za zapošljavanje trebaju: oživjeti i poticati osnivanje novih poduzeća, pomagati strane investicije, educirati i pripremiti stručnjaka na svim razinama uprave i mjesne samouprave. Vlada RH konkretnim se mjerama treba uključiti u zaštitu gospodarskih subjekata tijekom pandemije bolesti COVID-19 s naglaskom na realni sektor. Dok se u starim državama članicama EU-a izdatci za politiku zapošljavanja u proteklih 20 godina usmjeravaju na obučavanje i usavršavanje radnika u sklopu aktivnih mjera, u RH još uvijek prevladavaju pasivne mjere. Rezultat je toga niža radna aktivnost i porast rada nezaposlenih u ,sivoj“ ekonomiji.

Posebno je nužno urediti: 1. preuzimanje tereta doprinosa i poreza na dohodak u razdoblju dok traje stanje nepogode; 2. sufinanciranje plaća radnika spriječenih u radu izravno izazvanih mjerama za sprječavanje pandemije bolesti COVID-19; 3. uvesti bankama moratorij na naplatu rata kredita tvrtkama i radnicima; 4. donijeti hitnu izmjenu Zakona o radu uređujući radni odnos u doba nepogoda i prirodnih katastrofa te institut radnika na čekanju te 5. afirmirati fleksibilne radne odnose.

Hitne su mjere nužnost jer je u RH podijeljeno oko 15.000 otkaza (većinom hotelijerstvo i ugostiteljstvo), a oko 400.000 radnika je na čekanju. Teret posljedica bolesti COVID-19 i usporavanja gospodarstva ne može i ne smije biti stavljen isključivo na teret poslodavaca. Poslodavci u RH trebaju donijeti interni dogovor ili zaključak može li se i tko može koristiti fleksibilnu radnu aktivnost na daljinu, odrediti koji su to radnici i mjere nadzora njihovog rada. Poslodavci trebaju zatražiti izvanrednu procjenu rizika kako bi donijeli interne upute o postupanju radnika koji nastavljaju raditi iz poduzeća. Posebno je pitanje radnika koji ne mogu raditi niti uz mjere zaštite zdravlja. 
Fleksibilnost na tržištu rada treba koristiti u situacijama kao što su: zapošljavanje sa skraćenim radnim vremenom; rad od kuće; povremeno i privremeno angažiranje radnika; različiti oblici samozapošljavanja (individualno pružanje usluga, timsko angažiranje); rad vikendom te rad za pomoć u kući. Nužno je otvarati posebne agencije za prekvalifikaciju i preusmjeravanje radnika, koje će pružanjem informacija upućivati radnika u one poslovne subjekte gdje su njihova stručna znanja i sprema potrebni. Radnici u hotelijerstvu i ugostiteljstvu čiji su objekti zatvoreni mogli bi se uz određene preduvjete tada zaposliti u najširem spektru zdravstvenih i drugih ustanova koje bi radile na sprječavanju pandemije bolesti COVID-19. Iznos naknade plaće dok je radnik na čekanju može biti niži od iznosa ugovorene plaće u omjeru u kojem je poslodavac može isplaćivati, a u suprotnom šalje ga u drugi poslovni subjekt, putem agencije u vremenu dok je to potrebno.

\section{LITERATURA}

1. Arbutina, Hrvoje. „Porezni izdaci u kontekstu presuda Europskog suda: Aspekti oporezivanja dohotka i dobiti“. U: Zbornik radova s konferencije: Skrivena javna potrošnja i budućnost poreznih izdataka, ur. Vjekoslav Bratić i Martina Fabris, 197-206. Zagreb: Institut za javne financije, 2012.

2. Bačić, Petar i Ivan Sarić. „Kratka studija aktivizma europskog suda kroz presude o slobodi kretanja radnika“. Zbornik radova Pravnog fakulteta u Splitu 51, br. 1 (2014): 27-44.

3. Bejaković, Predrag. „Ispadanje iz obrazovanja kao odrednica zapošljivosti“. Radno pravo 4, br. 11 (2011): 53-61.

4. Bejaković, Predrag. „Materijalno-pravna zaštita nezaposlenih u Hrvatskoj i u odabranim zemljama“", Revija za socijalnu politiku 4, br. 3 (1997), www.rsp.hr/ojs2/index.php/rsp/ article/view/381/385

5. Bejaković, Predrag. „Nezaposlenost“. Financijska teorija i praksa 27, br. 4 (2003): 659661.

6. Benić, Đuro. Osnove ekonomije. 3. izd. Zagreb: Školska knjiga, 2001.

7. Benić, Đuro. „Povijest razvoja teorije o odnosu između inflacije i nezaposlenosti“. Ekonomska misao i praksa 2 (2014): 411-430.

8. Bušelić, Marija. Mjere za poticanje zapošljavanja u Republici Hrvatskoj: doktorska disertacija. Zagreb: Ekonomski fakultet, 2001.

9. Bušelić, Marija. Tržište rada: teorijski pristup. Pula: Fakultet ekonomije i turizma „Dr. Mijo Mirković", 2014.

10. Caro de Sousa Pedro. The European Fundamental Freedoms - A contextual approach. Oxford: Oxford University Press, 2015.

11. Crnković-Pozaić, Sanja. Fleksigurnost: posljednja barikada u borbi za radničku sigurnost. Pristup 4. svibnja 2020. https://lider.media/arhiva/14699/.

12. Crnković-Pozaić, Sanja et al. Tržište rada u Hrvatskoj. Zagreb: Ekonomski institut, 1994.

13. Deutsche Welle. Pristup 2. svibnja 2020. www.dw.de/deutsche-bankkratkoro\%C4\%8Dno-nema-pozitivnog-u\%C4\%8Dinka-ulaska-hrvatske-ueu/a-17868283

14. Družić, Ivo. Razvoj i tranzicija hrvatskog gospodarstva. Zagreb: HAZU, 1997.

15. Družić, Ivo. Resursi i tržišta hrvatskog gospodarstva. Zagreb: Politička kultura, 2004.

16. Družić, Ivo. „Tržišno restrukturiranje i privatizacija hrvatskoga gospodarstva“. U: Privatizacija hrvatskog gospodarstva, ur. Barić, Vinko et al., 137-173. Zagreb: Ekonomski fakultet Zagreb, Politička kultura, 2003. 
17. El-Agraa Ali M. The European Union - Economics and Policies. $8^{\text {th }}$ ed. Cambridge: Cambridge University Press, 2007.

18. Employment - annual statistics, Eurostat. Pristup 19. siječnja 2020. http://ec.europa.eu/ eurostat/statistics-explained/index.php/Employment_statistics

19. Europe 2020: A strategy for smart, sustainable and inclusive growth (COM(2010) 2020 final), Eurostat. Pristup 5. lipnja 2020. http://ec.europa.eu/eurostat/en/web/productsdatasets/-/UNE_RT_M.

20. Europski strukturni i investicijski fondovi, 2014.-2020. Pristup 18. svibnja 2020. www. prvikorak.eu/eu-fondovi-2014-2020.aspx.

21. Cazes, Sandrine i Alena Nesporova, ur. Fleksigurnost, Relevantan pristup za srednju $i$ istočnu Europu. Zagreb: TIM press, 2007.

22. Galić, Zvonimir. Nezaposlenost, traženje posla i zapošljavanje: longitudinalna analiza psiholoških aspekata: doktorska disertacija. Zagreb: Filozofski fakultet, 2008.

23. Gotovac, Viktor. „Radno pravo za 21. stoljeće: mitovi o fleksibilizaciji“. Financijska teorija i praksa 27, br. 4 (2003): 415-437.

24. Grbac, Bruno. Marketinške paradigme. Rijeka: Ekonomski fakultet Rijeka, 2010.

25. Greenberg, Daniel S. „Participation in Public Employment Programs“. U: Creating JobsPublic Employment Programs and Wage Subsidies, ed. John L. Palmer. Washington: The Brookings Institute, 1978.

26. Gregurek, Miroslav. „Stupanj i učinci privatizacije u Hrvatskoj“, Ekonomski pregled 52, br. 1-2 (2001): 155-188.

27. Hrvatski zavod za zapošljavanje. Pristup 15. svibnja 2020. www.hzz.hr.

28. Jašarević, Senad. „Radni odnos - tendencije u svijetu i u Srbiji“. Aktualnosti građanskog i trgovačkog zakonodavstva i pravne prakse br. 12 (2014): 299-308.

29. Jurković, Saša. Fleksigurnost - budućnost europskog zapošljavanja?. Pristup 4. svibnja 2020. www.posao.hr.

30. Jurković, Pero, Franjo Luković, Đorđe Pribičević i Slaven Ravlić, ur. Poslovni rječnik. Zagreb: Masmedia, 1991.

31. Kersan-Škabić Ines. Ekonomija Europske unije. Pula: Sveučilište Jurja Dobrile, Odjel za ekonomiju i turizam „Dr. Mijo Mirković“", 2012.

32. Korjenić, Omer. Globalizacija i tržište rada. Mostar: IC Štamparija, 2015.

33. Loje, Goran. „Fleksibilizacija tržišta rada“, Pravo i porezi 17, br. 10 (2008): 42-45.

34. Lowther, Joe. „Fleksibilnost radne snage i uloga hrvatskih socijalnih partnera u njezinu povećanju“, Financijska teorija i praksa 27, br. 4 (2003): 457-479.

35. Mazalin Kristina i Maja Parmač Kovačić, „Odrednice percipirane zapošljivosti studenata“, Društvena istraživanja 24, br. 4 (2015): 509-529.

36. Meškić, Zlatan i Darko Samardžić. Pravo Evropske unije I. Sarajevo: TDP, GIZ GmbH, Otvoreni Regionalni Fond za jugoistočnu Evropu - Pravna reforma, 2012.

37. Mihajlović, P. „Fleksibilne forme zapošljavanja u funkciji stvaranja uslova za veće zapošljavanje“, Pravni život 50, br. 10 (2001): 577-586.

38. Misita, Nevenko. Evropska unija - Institucije. Sarajevo: Revicon, 2009.

39. Mjere aktivne politike zapošljavanja. Pristup 5. veljače 2020. http://mjere.hr/

40. Mrnjavac, Željko. „Razlikovanje tipa nezaposlenosti - neizvodljiva misija“. Ekonomska misao i praksa 11, br. 2 (2002): 219-237.

41. Obadić Alka, „The Danish flexicurity labour market policy concept", EFZG working paper series br. 4 (2009): 1-15.

42. Obadić Alka i Ela Majić, „Analiza strukture nezaposlenih visokoobrazovanih osoba u Republici Hrvatskoj i mjere za njezino smanjenje“, Poslovna izvrsnost 7, br. 2 (2013): 103-123., https://hrcak.srce.hr/file/166401.

43. Ott, Katarina, ur. Javne financije u Hrvatskoj. 3. izd. Zagreb: Institut za javne financije, 2007. 
44. Pavić, Ivan, Đuro Benić i Iraj Hashi. Mikroekonomija. Split: Sveučilište u Splitu, 2006.

45. Psihološki aspekti nezaposlenosti. Zbornik radova XII. ljetne škole studenata $i$ nastavnika Odsjeka za psihologiju Filozofskog fakulteta u Zagrebu. Silba: Filozofski fakultet u Zagrebu, 2002.

46. Puljiz, Vlado, Gojko Bežovan, Teo Matković, Zoran Šućur i Siniša Zrinščak. Socijalna politika Hrvatske. Zagreb: Pravni fakultet u Zagrebu, 2008.

47. Senčur Peček, Darja i Sandra Laleta, „Ugovor o radu i ugovor o djelu: područje primjene radnog zakonodavstva“. Zbornik Pravnog fakulteta Sveučilišta u Rijeci 39, br. 1 (2018): 411-456.

48. Servais Jean-Michel. International Labour Law. $3^{\text {rd }}$ ed. The Hague: Wolters Kluwer, Law \& Business, 2011.

49. Starc, Nenad, ur. Siromaštvo, nezaposlenost i socijalna isključenost, Zagreb: Program UN za razvoj, 2006.

50. Statistička analiza nezaposlenosti u Republici Hrvatskoj 2000.-2010. Zagreb: Hrvatski zavod za zapošljavanje, 2012., http://e-lib.efst.hr/2012/7981260.pdf.

51. Strategija borbe protiv siromaštva i socijalne isključenosti u RH, 2014.-2020. Pristup 25. travnja 2020. file:///I: /hr\%202020.pdf.

52. Strateški plan ministarstva rada i mirovinskoga sustava 2013.-2015. Pristup 29. travnja 2020. https://vlada.gov.hr/UserDocsImages//ZPPI/Strategije\%20-\%20OGP/rad\%20i\%20 mirovinski\%20sustav//strateski-plan-2013-2015.

53. Strateški plan ministarstva rada i mirovinskoga sustava, 2015.-2017. Pristup 25. travnja 2020. http://www.mrms.hr/?s=strate\%C5\%A1ki+plan.

54. Škare, Marinko. „Nezaposlenost u Hrvatskoj i determinante potražnje za radom“. Revija za socijalnu politiku 8, br. 1 (2001): 19-34.

55. Tomašić, Petar. Nezaposlenost u tranzicijskoj Hrvatskoj pod socijalno-etičkim vidom. Zagreb: Kršćanska sadašnjost, 2010.

56. Učur, Marinko Đ. i Sandra Laleta. Konvencije Međunarodne organizacije rada. Zagreb: TIM press, 2007.

57. Vukelić, Anton. Anomija pojedinih socijalnih grupa suvremenog hrvatskog društva: doktorska disertacija. Zagreb: Pravni fakultet, 2002.

58. Weiss Friedl, Klaupa Clemens. European Union Internal Market Law. Cambridge: Cambridge University Press, 2014.

59. Zakon o izmjenama i dopunama Zakona o posredovanju pri zapošljavanju i pravima za vrijeme nezaposlenosti, Narodne novine, br. 25/12.

60. Zakon o posredovanju pri zapošljavanju i pravima za vrijeme nezaposlenosti, Narodne novine, br. 12/13.

61. Zaposlenost - godišnja statistika, Eurostat. Pristup 5. lipnja 2020. https://ec.europa.eu/ eurostat/statistics-explained/index.php?title=Employment_statistics/hr\#Dodatni_podaci Eurostata

62. Žužul, M. „Neke karakteristike djece čiji su roditelji na radu u inozemstvu“, Rasprave o migracijama 63 (1980): 39-58. 


\section{Nenad Božiković*}

Summary

\section{LABOUR MARKET IN THE EUROPEAN UNION AND THE REPUBLIC OF CROATIA}

The Croatian economy is characterized by high unemployment and slow opening dynamics new jobs due to several factors, including an inflexible labour market. Work gives theoretical overview of labour market components, labour market supply and demand, discrimination on labour market, flexicurity, unemployment as well as the issue of employment policy comparing trends in the EU and the Republic of Croatia, and the conclusion discusses concrete measures to improve the situation in labour market in the Republic of Croatia.

Keywords: labour market; unemployment; discrimination; employment policy.

* Nenad Božiković, Ph.D., Professor and external associate of Banja Luka College; jbozikovina@, gmail.com. ORCID: https://orcid.org/0000-0001-6140-0639. 